\title{
Performance and Haemato-Biochemical
}

\section{Supplemented with Dried Water Melon Peel (Rind) Meal}

\author{
Alagbe J0* \\ Department of Animal Science, University of Abuja, Nigeria
}

Submission: November 15, 2018; Published: January 09, 2019

"Corresponding author: Alagbe JO, Department of Animal Science, University of Abuja, Nigeria.

\begin{abstract}
A study was carried out to investigate the performance, hematological and serum biochemistry of weaner rabbits given feed formulated with dried water melon peel meal (WMR). Thirty rabbits of mixed breed aged 7-8 weeks with initial weight of 602-616g were used in a completely randomized design (CRD) with six replicates per treatment. The animals were fed varied levels of WMR at $0 \%, 2.0 \%, 4.0 \%, 6.0 \%$ and $8.0 \%$ to obtain five diets. The control diet was prepared to meet the nutritional standards of growing rabbits and it lasted for 12 weeks. Results revealed that there was no significant ( $p>0.05$ ) differences in the values obtained for the growth performance among the treatments. Hematological and all the blood serum biochemical traits measured were not a significantly different by the dietary inclusion of WMR. It was concluded that dried water melon peels (WMR) can be included up to $8.0 \%$ in the diets of weaner rabbits without deleterious effect on the performance, hematological and serum biochemical parameters of rabbits.
\end{abstract}

Keywords: Water melon peels; Performance; Hematology; Blood; Weaner rabbits

Abbrevations: WMR: Water Melon Peel Meal; CRD: Completely Randomized Design; PCV: Pack Cell Volume; EDTA: Ethylene Diamine Tetra Acetate; RBC: Red Blood Cell; WBC: White Blood Cell; Hb: Haemoglobin Concentration; MCV: Mean Corpuscular Volumes; MCH: Mean Corpuscular Haemoglobin; MCHC: Mean Corpuscular Heamoglobin Concentration; SGOT: Glutamic Oxaloacetate Transaminase; SGPT: Glutamic Phosphatase Transaminase; AAS: Atomic Absorption Spectrophotometer

\section{Introduction}

Protein is the basic structural material from which all body tissues are formed and it has been reported its intake of most developing countries including Nigeria is very low due to the high cost of victual; With the rapid increase in the population rate, there have additionally been an increase in competition among feed stuffs which are also used in feed making with human beings, sundry efforts are been made by Animal nutritionist in order to provide solution to the low protein intake especially from animals to increment the caliber of animal protein intake of the populace by probing for alternatives that are more frugal sources of feed ingredients to procure prosperity in livestock management. The utilization of unconventional feedstuffs and forages which are not consumed by humans can be used to produce animal feeds [1]. Among such alternatives is the use of water melon peels which is found abundant in minerals/ vitamins and can be used to feed animals like rabbits due to fast growing characteristics and their ability to convert tropical forages and agricultural by products to human food (meat).

Water melon belongs to the family to the family Cucurbitaceae and the species Citrullus landaus. They are widely distributed in the tropics and subtropics [2,3]. It contains low energy and high level of micronutrients such as carotene, vitamin k, ascorbic acid, riboflavin, iron, iodine and other mineral elements. It has been established that water melon peels are found in many places in Nigeria Gin et al. [4]. Watermelon rinds may have additional medical benefits. Research by the Agricultural Research Service discovered that watermelon rinds contain citrulline. Citrulline creates arginine, an amino acid that makes proteins for the body and plays a role in the relaxation of blood vessels [5].

Rabbits (Oryctolagus cuniculus meat are rich in protein and other nutrients which are safe for human consumption [6]. It has a feeding habits with no appreciable competition with man, this is because it can subsist on green as basal diet. Rabbits can easily utilize waste to produce meat giving it an advantage over other animal species like poultry. Although extensive studies had shown that WMR had an appreciable quantity of phytochemical and antioxidant, proximate components and anti-nutritional factors of water Johnson et al. [7], on effect of water melon rinds on the nutrient composition, performance and carcass characteristics of albino rats [8], but there are no information on supplementing dried water melon rinds on the general performance and blood profile of rabbits. An experiment on WMR inclusion in animals (rabbits) will give a clue on its safety margin during dietary supplementation and as an alternative 
unconventional agricultural feed stuff. The main aim of this study was to investigate the growth performance and haematobiochemical parameters of growing rabbits fed varying inclusion levels of dried water melon peel (rind) meal (Figure 1).

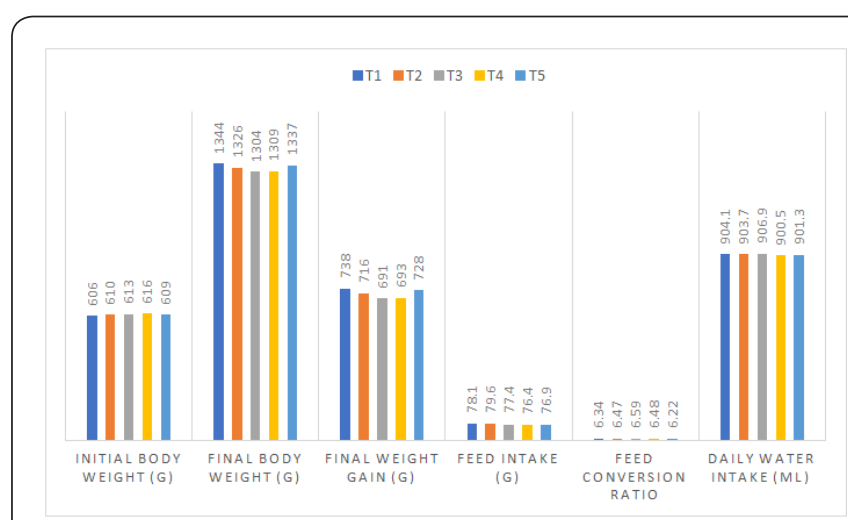

Figure 1: Performance chart of growing rabbits fed varying levels of WMR.

\section{Methodology}

\section{Experimental Site}

This study was carried out at the Livestock Teaching and Research Farm of University of Abuja, Gwagwalada, AbujaNigeria. Collection and processing of water melon rinds (WMR) Fresh healthy water melon fruit were collected from Gwagwalada, Abuja. The fruit was thoroughly cleaned remove sand particles after which they were sliced with cleaned knife to separate the rind from the pulp. The rind was cut into pieces and sundried for 6 days, the dried rinds were then milled in a hammer mill to form water melon rind meal (WMR).

\section{Pre-experimental operations}

A total of thirty, 7-8 weeks bucks cross breed rabbits (Chinchilla $\times$ New Zealand White) with an average weight of $602 \mathrm{~g}$ and $616 \mathrm{~g}$ were used for this experiment. They were individually housed in a an all wire cages measuring $50 \mathrm{~cm} \times 35 \mathrm{~cm} \times 40 \mathrm{~cm}$ (width $\times$ length $\times$ height) and equipped with feeding and watering troughs. The cages were cleaned and disinfected before the arrival of the animals. The rabbits were allowed two week adjustment period during which they were fed with control diet and given prophylactic treatment of Oralmectin against endo and ecto- parasites before they were placed on the experimental diets.

\section{Animal management, experimental diets and design}

Five diets were formulated to meet the nutritional requirements of growing rabbits. Control diet (T1) did not contain WMR, while diets T2, T3, T4 and T5 contained WMR at $2.0 \%, 4.0 \%, 6.0 \%$ and $8.0 \%$ respectively. Experimental design used was a completely randomized design. The animals were fed twice daily at 7:30 hour and 14:30 hour, feed and clean water was supplied the performance of the rabbits in terms of feed intake and mortality were recorded daily and all management practices were strictly observed throughout the experiment which lasted for 12 weeks.

\section{Blood Analysis}

On the 12th week of the experiment, blood samples were collected from the marginal vein of three randomly selected rabbits per treatment. The blood samples were analyzed for some hematological and serum biochemical parameters; blood samples for hematology were collected into bottles containing Ethylene Diamine Tetra Acetate (EDTA). The hematological parameters such as Pack cell volume (PCV), Red blood cell (RBC), White blood cell (WBC), Haemoglobin concentration ( $\mathrm{Hb}$ ) and absolute counts of neutrophils, lymphocytes, monocytes and eosinophils were computed according to the method. The Mean corpuscular volumes (MCV), mean corpuscular haemoglobin (MCH), Mean corpuscular heamoglobin concentration (MCHC) were calculated according to Bush [9]. Blood samples that were meant for serum biochemistry were collected into other bottles free from any anticoagulant. The serum total protein, Albumin and Globulin were computed according to, Uric acid, Creatinine, Glutamic oxaloacetate transaminase (SGOT) and Glutamic phosphatase transaminase (SGPT) was determined according to Scott [10].

\section{Laboratory Analysis}

The proximate composition of experimental diets and WMR were analyzed according to AOAC (2000), while phytochemical analysis was determined according to Harbone [11]. The mineral analysis were carried out using Atomic Absorption Spectrophotometer (AAS). Vitamin content of WMR were analyzed using method reported by Onwuka [12].

\section{Statistical Analysis}

Data were analyzed using the general linear model procedures of Statistical Analysis Systems software with the model containing treatments. Differences between treatment means were separated using (SAS, 2009). Significant differences were declared at $(\mathrm{p}<0.05)$

\section{Results and Discussion}

Table 1: 1Premix supplied per kg diet :- Vit A, 7,000 I.U; Vit E, 5mg; Vit D3, 3000I.U, Vit K, 6mg; Vit B2, 5.5mg; Niacin, $25 \mathrm{mg}$; Vit B12, $16 \mathrm{mg}$; Choline chloride, $120 \mathrm{mg}$; Mn, $5.2 \mathrm{mg} ; \mathrm{Zn}, 25 \mathrm{mg}$; Cu, $2.6 \mathrm{~g}$ ; Folic acid, $2 \mathrm{mg}$; Fe, $5 \mathrm{~g}$; Pantothenic acid, $10 \mathrm{mg}$; Biotin, $30.5 \mathrm{~g}$; Antioxidant, $20 \mathrm{mg}$

\begin{tabular}{|c|c|c|c|c|c|}
\hline Materials & \multicolumn{5}{|c|}{ Treatments } \\
\hline & T1 & T2 & T3 & T4 & T5 \\
\hline Maize & 15 & 15 & 15 & 15 & 15 \\
\hline Wheat offal & 30 & 28 & 26 & 24 & 22 \\
\hline $\begin{array}{c}\text { Groundnut } \\
\text { cake }\end{array}$ & 10.75 & 10.75 & 10.75 & 10.75 & 10.75 \\
\hline Soya meal & 5 & 5 & 5 & 5 & 5 \\
\hline $\begin{array}{c}\text { Palm } \\
\text { kernel } \\
\text { meal }\end{array}$ & 35 & 35 & 35 & 35 & 35 \\
\hline Bone meal & 2.5 & 2.5 & 2.5 & 2.5 & 2.5 \\
\hline Limestone & 1 & 1 & 1 & 1 & 1 \\
\hline
\end{tabular}




\section{Archives of Animal \& Poultry Sciences (AAPS)}

\begin{tabular}{|c|c|c|c|c|c|}
\hline Lysine & 0.1 & 0.1 & 0.1 & 0.1 & 0.1 \\
\hline Methionine & 0.1 & 0.1 & 0.1 & 0.1 & 0.1 \\
\hline 1Premix & 0.25 & 0.25 & 0.25 & 0.25 & 0.25 \\
\hline Salt & 0.3 & 0.3 & 0.3 & 0.3 & 0.3 \\
\hline WMR & 0 & 2 & 4 & 6 & 8 \\
\hline Total & 100 & 100 & 100 & 100 & 100 \\
\hline
\end{tabular}

A: Percentage Composition of Experimental Diets.

\begin{tabular}{|c|c|c|c|c|c|}
\hline $\begin{array}{c}\text { Protein } \\
(\%)\end{array}$ & 17.81 & 16.97 & 16.56 & 16.48 & 16.4 \\
\hline $\begin{array}{c}\text { Crude } \\
\text { fibre (\%) }\end{array}$ & 10.24 & 10.45 & 10.52 & 10.88 & 11.01 \\
\hline $\begin{array}{c}\text { Ether } \\
\text { extract } \\
(\%)\end{array}$ & 2.52 & 2.41 & 2.35 & 2.28 & 2.12 \\
\hline Ash (\%) & 6.11 & 5.67 & 5.37 & 5.25 & 5.19 \\
\hline $\begin{array}{c}\text { ME } \\
(\mathrm{kcal} / \\
\mathrm{kg})\end{array}$ & 2638.5 & 2634.7 & 2633.1 & 2630.9 & 2603.1 \\
\hline
\end{tabular}

B: Nutrient Composition (calculated).

The proximate results obtained for the experimental diets is presented in Table 1 . The crude protein, crude fibre, ash, ether extract and energy in the diet ranges from $16.40 \%-17.81 \%$, 10.24\%-11.10\%, 5.19\% - 6.11\%, 2.28\% - 2.52\% and $2603.1-$ 2638.5 (MEkcal/kg) respectively. In the current study Crude fibre shows an increasing trend as increasing of inclusion level of WMR. This was in agreement with the findings. However, proximate composition in the experimental diets was within the range recommended for growing rabbits NRC (1977); Adaku \& Olukosi [13]; Anugwa et al. [14]; Alagbe et al. [15] and Ibrahim et al. [16].

Table 2: Proximate Composition of WMR.

\begin{tabular}{|c|c|}
\hline Parameters & \% Composition \\
\hline Crude protein & $7.45 \pm 0.01$ \\
\hline Crude fibre & $18.57 \pm 0.03$ \\
\hline Ether extracts & $10.44 \pm 0.78$ \\
\hline Ash & $3.22 \pm 0.12$ \\
\hline
\end{tabular}

The results on the proximate composition of WMR is presented in Table 2. WMR contained $7.45 \%$ crude protein, $18.57 \%$ crude fibre, $10.44 \%$ ether extract and $3.22 \%$ ash. The current study is in line with the findings of Feumba et al. [17] and Johnson et al. [7] who reported similar results on chemical evaluation of many dried fruits.

Table 3: Phytochemical Analysis of WMR.

\begin{tabular}{|c|c|}
\hline Parameters & (\%) Composition \\
\hline Flavonoids & $1.03 \pm 0.01$ \\
\hline Alkaloids & $1.01 \pm 0.04$ \\
\hline Tannins & $0.79 \pm 0.12$ \\
\hline Saponins & $2.12 \pm 0.01$ \\
\hline Phytate & $1.23 \pm 0.88$ \\
\hline
\end{tabular}

Table 3 reveals the phytochemical analysis of water melon rinds (WMR), the phytochemical components are $1.03 \%$ flavonoids, $1.01 \%$ alkaloids, $0.79 \%$ tannin, $2.12 \%$ saponins and $1.23 \%$ phytate respectively while those of minerals are $0.47 \mathrm{mg}$ copper, $1.31 \mathrm{mg}$ iron, $1.02 \mathrm{mg}$ zinc, $30.02 \mathrm{mg}$ calcium, $1.44 \mathrm{mg}$ magnesium, $1.12 \mathrm{mg}$ potassium, $0.77 \mathrm{mg}$ sodium, $131.1 \mathrm{mg}$ phosphorus, $1.18 \mathrm{mg}$ manganese and $0.13 \mathrm{mg}$ selenium respectively as presented in Table 4. The trend of mineral concentration in WMR in decreasing order is $\mathrm{P}>$ $\mathrm{Ca}>\mathrm{Mg}>\mathrm{Fe}>\mathrm{K}>\mathrm{Mn}>\mathrm{Zn}>\mathrm{Na}>\mathrm{Cu}>\mathrm{Se}$, this mineral trend agrees with the report of Gladvin et al. [2]; Olayinka \& Etejere [18], on the mineral and vitamin content in water melon peel.

Table 4: Mineral composition of WMR

\begin{tabular}{|c|c|}
\hline Parameters & (\%) Composition \\
\hline Copper & $0.47 \pm 0.00$ \\
\hline Iron & $1.31 \pm 0.01$ \\
\hline Zinc & $1.02 \pm 0.03$ \\
\hline Calcium & $30.02 \pm 3.10$ \\
\hline Magnesium & $1.44 \pm 0.01$ \\
\hline Potassium & $1.12 \pm 0.03$ \\
\hline Sodium & $0.77 \pm 0.02$ \\
\hline Phosphorus & $131.3 \pm 1.22$ \\
\hline Manganese & $1.18 \pm 0.04$ \\
\hline Selenium & $0.13 \pm 0.01$ \\
\hline
\end{tabular}

Onwuka [12] and Adeyeye [19], reported that Minerals is always required for efficient metabolic processes. Calcium and phosphorus are major components of the skeletal system, magnesium is a component of the bone, a cofactor of several enzyme activity and is involved in the transmission of nerve impulses, copper is significant in iron and energy metabolism while sodium and potassium play key roles in the acid-base regulation of the blood and other body fluids Amy E Halls [20].

Table 5: Composition of Vitamins in WMR

\begin{tabular}{|c|c|}
\hline Parameters & (\%) Composition \\
\hline Vitamin A & $56.81 \pm 6.31$ \\
\hline Vitamin B1 & $1.22 \pm 0.01$ \\
\hline Vitamin B2 & $2.33 \pm 0.06$ \\
\hline Vitamin B3 & $5.01 \pm 0.10$ \\
\hline Vitamin C & $58.12 \pm 0.05$ \\
\hline
\end{tabular}

Phytochemical results of WMR in this current study was also consistent with report of Egbonu [21]; Ella et al. [22] and Hanan et al. [23]. According to Bako et al. [24] phytochemicals vary in distribution within the plant parts as well as in their occurrence within the plant species and have also been reported to reduce the risk of some diseases due to their protective and therapeutic roles Adesanya \& Sofowora [25]. According to Adisa et al. [26], tannins are known to possess antibacterial and anti-viral activity, saponin plays a significant role in maintaining blood cholesterol levels [27]. Adesanya \& Sofowora, [25] reported that phenol plays a vital role in red blood cell modifier. Results on the 
vitamins composition of WMR (Table 5) revealed that Vitamin A contains 56.81mg, 1.22 vitamin B1, 2.33mg B2, $5.01 \mathrm{mg}$ B3

and $58.12 \mathrm{mg} C$ respectively. Vitamin $\mathrm{C}$ had the highest number followed by vitamin A, B3, B2 and B1.

Table 6: Performance traits of growing rabbits fed varying inclusion levels of WMR.

\begin{tabular}{|c|c|c|c|c|c|c|}
\hline Parameters & T1 & $\mathrm{T} 2$ & T3 & T4 & T5 & \\
\hline & $0 \%$ & $2 \%$ & $4 \%$ & $6 \%$ & $8 \%$ & $\mathrm{~S} / \mathrm{L}$ \\
\hline Initial live wgt (g) & $606 \pm 31.4$ & $610 \pm 22.1$ & $613 \pm 27.2$ & $616 \pm 40.4$ & $609 \pm 41.4$ & Ns \\
\hline Final live wgt (g) & $1344 \pm 24.6$ & $1326 \pm 34.3$ & $1304 \pm 30.6$ & $1309 \pm 41.1$ & $1337 \pm 39.8$ & Ns \\
\hline FWG (g) & $738 \pm 3.02$ & $716 \pm 5.31$ & $691 \pm 7.80$ & $693 \pm 4.41$ & $728 \pm 6.12$ & Ns \\
\hline Feed intake (g) & $78.1 \pm 1.31$ & $79.6 \pm 3.01$ & $77.4 \pm 2.53$ & $76.4 \pm 2.61$ & $76.9 \pm 1.77$ & Ns \\
\hline FCR & $6.34 \pm 0.43$ & $6.47 \pm 0.32$ & $6.59 \pm 0.01$ & $6.48 \pm 1.10$ & $6.22 \pm 0.78$ & Ns \\
\hline DWI (ml) & $904.1 \pm 1.23$ & $903.7 \pm 1.02$ & $906.9 \pm 0.07$ & $900.5 \pm 0.19$ & $901.3 \pm 0.21$ & Ns \\
\hline Mortality & $0 / 6$ & $0 / 6$ & $0 / 6$ & $0 / 6$ & $0 / 6$ & \\
\hline
\end{tabular}

Ns: No significant $(p>0.05)$ difference

Generally, Vitamins are very vital components in food because of their role in proper functioning and body metabolic activity [28]. Vitamin C protects the body from oxidative stress and maintains the immune system, their synergistic combination with other vitamins allows proper growth, high reproductive performance and enzymatic activities. The results obtained for WMR is in agreement with the reports of Collins et al. [29];
Leterme et al. [30]; Moon and Shibamoto [31] as presented in Table 6. Supplementation of (WMR) at different levels in growing rabbits showed no significant effect on their feed intake, body weight change and feed conversion ratio (FCR) in the current study. This was similar with the finding of Alagbe J 0 [32]; Haruna \& Muhammad [33].

Table 7: Hematological parameters of growing rabbits fed varying inclusion of WMR.

\begin{tabular}{|c|c|c|c|c|c|c|}
\hline Parameters & Treatments & T2 & T3 & T4 & T5 & T5 \\
\hline $\begin{array}{c}\text { Pack cell volume } \\
\text { (\%) }\end{array}$ & T1 & T2 & T3 & T4 & $57.32 \pm 0.12$ & Ns \\
\hline Hemoglobin (g/dl) & $8.13 \pm 0.09$ & $11.3 \pm 0.05$ & $13.13 \pm 0.07$ & $13.15 \pm 0.10$ & $13.44 \pm 0.17$ & Ns \\
\hline RBC (×106/L) & $6.11 \pm 0.19$ & $7.01 \pm 0.17$ & $7.11 \pm 0.15$ & $7.18 \pm 0.45$ & $7.33 \pm 0.56$ & Ns \\
\hline MCV (fl) & $60.11 \pm 0.87$ & $63.12 \pm 0.66$ & $68.10 \pm 0.1$ & $69.14 \pm 0.09$ & $70.19 \pm 1.22$ & Ns \\
\hline MCH (pg) & $19.18 \pm 1.22$ & $19.45 \pm 1.34$ & $20.14 \pm 1.82$ & $20.44 \pm 1.09$ & $20.66 \pm 1.54$ & Ns \\
\hline MCHC (\%) & $30.10 \pm 0.56$ & $31.23 \pm 0.97$ & $31.77 \pm 0.87$ & $32.10 \pm 0.37$ & $32.51 \pm 0.66$ & Ns \\
\hline WBC (×106/L) & $10.02 \pm 0.89$ & $10.66 \pm 0.78$ & $11.03 \pm 0.80$ & $11.35 \pm 0.91$ & $12.10 \pm 0.82$ & Ns \\
\hline Lymphocytes (\%) & $50.12 \pm 0.34$ & $51.71 \pm 0.54$ & $52.13 \pm 0.65$ & $52.33 \pm 0.80$ & $52.36 \pm 0.36$ & Ns \\
\hline Monocytes (\%) & $1.31 \pm 0.05$ & $1.28 \pm 0.01$ & $1.23 \pm 0.03$ & $1.27 \pm 0.00$ & $1.20 \pm 0.03$ & Ns \\
\hline Neutrophils (\%) & $33.12 \pm 1.10$ & $33.03 \pm 1.26$ & $33.18 \pm 1.14$ & $33.27 \pm 1.53$ & $33.10 \pm 1.10$ & Ns \\
\hline Basophils (\%) & $0.72 \pm 0.05$ & $0.67 \pm 0.01$ & $0.58 \pm 0.00$ & $0.71 \pm 0.02$ & $0.69 \pm 0.01$ & Ns \\
\hline Eosinophils (\%) & $5.11 \pm 0.04$ & $4.54 \pm 0.18$ & $4.32 \pm 0.01$ & $4.59 \pm 0.02$ & $5.01 \pm 0.06$ & Ns \\
\hline
\end{tabular}

Ns: No significant $(p>0.05)$ difference.

According to Ojabo et al. [34] the use of Sweet orange peel in the diet of growing rabbits produced no significant increase in feed intake, final body weight and FCR when compared to a control diet but contrary with the reports of Ishaya B. Kaga [35] on the performance of rabbits fed Delonix regia meal. The water intake values obtained are practically the same and mortality was recorded throughout the experimental period, this could be due to proper hygiene, biosecurity measures and the safety margin of including WMR in the diet of the animal as presented in Table 7.

Table 8: Serum biochemical profile of growing rabbits fed varying inclusion levels of WMR.

\begin{tabular}{|c|c|c|c|c|c|c|}
\hline Parameters & Treatments & T2 & T3 & T4 & T5 & T1 \\
\hline $\begin{array}{c}\text { Total protein (g/ } \\
\text { dl) }\end{array}$ & T1 & T1 & T1 & T1 & S/L \\
\hline
\end{tabular}




\section{Archives of Animal \& Poultry Sciences (AAPS)}

\begin{tabular}{|c|c|c|c|c|c|c|}
\hline Albumin (g/dl) & $2.34 \pm 0.45$ & $2.61 \pm 0.31$ & $2.47 \pm 0.65$ & $2.66 \pm 0.12$ & $2.56 \pm 0.18$ & Ns \\
\hline Globulin (g/dl) & $2.11 \pm 0.03$ & $2.13 \pm 0.08$ & $2.09 \pm 0.61$ & $2.16 \pm 0.80$ & $2.31 \pm 0.01$ & Ns \\
\hline Uric acid (mg/l) & $10.4 \pm 0.01$ & $10.1 \pm 0.04$ & $10.7 \pm 0.91$ & $11.2 \pm 0.06$ & $11.5 \pm 0.03$ & Ns \\
\hline Creatinine (mg/l) & $7.12 \pm 0.12$ & $8.87 \pm 0.18$ & $8.90 \pm 0.44$ & $9.10 \pm 0.39$ & $9.22 \pm 0.83$ & Ns \\
\hline SGOT (U/L) & $14.60 \pm 0.01$ & $12.23 \pm 0.03$ & $12.54 \pm 0.21$ & $12.32 \pm 0.14$ & $12.03 \pm 0.03$ & Ns \\
\hline SGPT (U/L) & $8.44 \pm 0.33$ & $8.41 \pm 0.26$ & $8.23 \pm 0.00$ & $8.03 \pm 0.35$ & $8.01 \pm 0.66$ & Ns \\
\hline
\end{tabular}

Ns: No significant $(p>0.05)$ difference.

Results on the blood hematological parameters of weaner rabbits fed diets supplemented with water melon peels is presented in Table 8. The values of PCV obtained is between $39.06 \%-57.32 \%$, hemoglobin values of $8.13-13.44$ (g/dl) while RBC values are $6.11-7.33((\times 106 / \mathrm{L})$. The PCV values fall within the normal ranges of $35-60 \%$ previously reported by Aduku and Olukosi [20]; Flecknell [36]. All the hematological parameters obtained in this study showed that were not significantly ( $p>0.05$ ) influenced by the dietary inclusion of WMR. The PCV, $\mathrm{Hb}, \mathrm{RBC}, \mathrm{MCV}, \mathrm{MCHC}$ and WBC values obtained slightly increased from diet 1 to 5 though not at a significant level. The parameters observed in this study were within the normal ranges for rabbits reported by Mituka and Rawnsley [37].

Togun and Oseni [38] reported that hematological analysis is useful in disease diagnosis and nutritional stress. It also provides the opportunity to clinically investigate the presence of several metabolites and other constituents in the body (Doyle, 2006). Nutrition and dietary contents affect the blood profile of healthy animals [39]; Addass et al. [40]. Esonu et al. [41] posited that haematological parameters like haematocrit value, hemoglobin concentration, white blood cell count, red blood cell count are dictate the level of oxygen in the blood. Blood parameters are excellent medium for measurement of potential biomarkers, because its collection is relatively non-invasive and it shows an enormous range of physiological process in the body at any given time. Changes in blood profile can be due to disease and nutritional stress Afolabi et al. [42], age and sex [43] and breed.

Table 8 shows the serum biochemistry of rabbits fed diets supplemented with WMR. The results revealed that the values obtained in this study were not significantly $(p>0.05)$ different by the dietary inclusion of WMR across the treatment. The total protein values obtained is $4.45-4.87(\mathrm{~g} / \mathrm{dl})$ which fall within the normal ranges of $5.40-7.50(\mathrm{~g} / \mathrm{dl})$ previously reported by Medirabbit [44], this shows that the protein level in the diet is in line with the nutritional requirement of the animal, which will assist in tissue and cell rebuild after stress. Uric acid values obtained are $10.4,10.1,10.7,11.2$ and 11.5 (mg/l) for diets 1,2 , 3,4 and 5 respectively while those of creatinine $(\mathrm{mg} / \mathrm{l})$ are 7.12 , $8.87,8.90,9.10$ and 9.22 for diets $1,2,3,4$ and 5 respectively. The values of SGOT obtained ranges between 12.03 and 14.60 (U/L) while those SGPT (8.01 - 8.44U/L) fall within the normal ranges reported by Ozkan et al. [45], on the normal biochemical parameters of New Zealand white rabbits [46-52]. This therefore implies that the test material (WMR) inclusion in the diet did not affect the liver of the animals [53-56].

\section{Conclusion}

WMR could be included in the diet of weaner rabbits up to $6 \%$ without any deleterious effect on the health and general performance of rabbits without causing any pathological abnormalities in their blood profile.

\section{References}

1. Asar MA, Osman M, Yakout HM, Safoat A (2010) Utilization of Corncob meal and faba bean straw in growing rabbits diets and their performance, digestibility and economical efficiency. Egypt Poultry Science 30(2): 415-442.

2. Gladvin G, Sudhaakr G, Swathi V and Santhisri K (2017) Mineral and vitamin content in water melon peel. International Journal of Current Applied Science, pp. 129-133.

3. Yamaguchi M (2006) World Vegetables: Principles, Production and Nutritive Values. AVI Publishing Co, Westport, USA.

4. Gin WA, Jimoh A, Abdulkareem AS, Giwa A (2014) Production of activated carbon from watermelon peel. International Journal of Scientific \& Engineering Research 5(2).

5. Lius Pons (2003) Exploring important medicinal uses for watermelon rinds. United States Department of Agriculture. Agricultural Research Service.

6. Owen JE (1981) Rabbit meat production for developing countries. Biochemistry Journal 3(2): 2-11.

7. Johnson JT, Iwang EU, Hemen JT, Odey MO, Effiong EE and Eteng OE (2012) Evaluation of anti-nutrients contents of watermelon Citrullus lanatus. Annals of Biological Research. 3(11): 5145-5150.

8. Okai DB, Boateng M, Amaoh KO and Johnson LD (2010) Studies on dried water melon rinds on the nutrient composition and effects on growth performance and carcass characteristics of Albino rats.

9. Bush BM (1991) Interpretation of Laboratory Results for Small Animal Clinicals. Blackwell scientific publication London, UK, pp. 515-575.

10. Scott HM (1965) Measurement of Albino Acid content of fish meal protein by chick growth assay. P.Sc pp. 395-465.

11. Harbone IB (1973) A guide to modern techniques to plant analysis. Chapman and hall, New York, USA.

12. Onwuka GI (2005) Feed analysis and instrumentation: theory and practice Naphthalic prints Surulere Lagos pp. 219-230

13. Adaku AO, Olukosi (1990) Rabbit management for the tropics: production, processing, utilization, marketing economic practical training research and future prospects. Living books Series, Abuja, Nigeria.

14. Anugwa FOI, Adesua M and Ikurior SA (1998) Effects of dietary crude fibre levels on the performance, nutrient digestibility and carcass characteristics of weanling- growing rabbits. Proceedings of the $25^{\text {th }}$ Silver Conference of the Nigeria Society of Animal Production Abeokuta. 
15. Olatunji AK, Alagbe JO and Hammed MA (2016) Effects of varying level of Moringa olifera on the performance of weaner rabbits. International Journal of Science and Research 5(6)

16. Ibrahim H, Hassan MR, Abdu SB, Chidinma F, Aliyu ZI, Bello SS and Ishiaku YM (2018) Blood biochemical profile and carcass characteristics of weaner rabbits fed varying levels of Gamba grass (Andropogon gayanus Kunth) forage. Nigeria Journal of Animal Science20(4): 522-560.

17. Feumba Dibanda Romelle, Ashwini Rani P and Ragu Sai Manohar (2016) Chemical composition of some selected fruit peels. European Journal of Food Science and Technology 4(4): 12-21.

18. Olayinka BU and Etejere EO (2018) Proximate and chemical composition of (Citrullus lanatus) and Cucumber. International Food Research Journal 25(3): 1060-1066.

19. Adeyeye EI (2000) Bio-concentrations of macro and trace minerals in four prawns living in Lagos lagoon. Pak J Scient Ind Res Vol 43: 367373.

20. Amy E Halls (2014) Nutrient requirements for rabbits. Shur-Gain Nutreco Canada Inc.

21. Egbuonu ACC (2015) Assessment of some anti-nutrient properties of water melon rind and seeds. Research Journal of Environmental Sciences 9: 225-232.

22. Ella WA, Ham EH, Johnson JT, Odey MO, Effiong EE, et al. (2013) Comprehensive proximate compositions of water melon. International Journal for Science and Technology. 2(1): 81-88.

23. Hanan MA, Al-Sayed, Abdelrahman R Ahmed (2013) Utilization of water melon rinds and sharly melon peels as a natural source of dietary fibre and antioxidant in cake. Elsevier Annals of Agricultural Science. 58(1): 83-95

24. Bako SP, Bakfur MJ, John I and Bela EL (2005) Int Jour Bot 1(2): 147150 .

25. Adesanya and Sofowora (1983) Biological standardization of Zanthoxylum roots for antisickling activity. Planta Medica. 48(1): 27 33.

26. Adisa RA, Choudhary EA, Adenoye GA and Olorunsogo 00 (2010) Hypoglycaemic and biochemical properties of Cnestis ferruinea. African Jou Complementary Alternative Medicine 7(3): 185-194.

27. Cheeke ON and Nobert HO (2000) Serum biochemical parameters in clinically healthy dogs in Ibadan. Tropical Vert 16: 3-4.

28. Farinu GO, Odunsi AA and Akinlade JA (2005) Introduction to animal nutrition. Oluseyi Printing Press Ltd Ibadan ISBN 978-169-332-2.

29. Collins GW, Perkins-veazie K, Spears PL, Claypool RA and Baker BA (2007) Water melon consumption increases plasma arginine concentrations in adult. Nutr Mar 23(3): 261-266.

30. Leterme P, Buldgen A, Estrada F and Londono AM (2006) Mineral components of tropical fruits and unconventional foods of Andes and rain forest of Colombia. Food Chemistry 95: 644-652.

31. Moon JK and Shibamoto T (2009) Antioxidant assay for plants and food components. Journal of Agriculture and Food Chemistry. 57(5): 16551666.

32. Alagbe JO (2017) Nutritional evaluation of sweet orange (Citrus sinensis) fruit peel as replacement for maize in the diet of weaner grass cutters. Scholarly Journal of Agricultural Science 6(8): 27-282.

33. Haruna IM and Muhammed AS (2018) Carcass characteristics of weaner fed concentrate diets with graded levels of yam peel meal. Nigerian Journal of Animal Science, 20(4): 561-566.

34. Ojabo LD, Adenkola AY and Odaudu GI (2012) Effects of dried sweet orange peel meal on the performance and heamatology of rabbits. Veterinary Research, 5(2): 26-30.
35. Ishaya B Kaga (2013) Biological and carcass characteristics of rabbits fed Delonix regia meal diets. Biological System Open Access 2(4).

36. Flecknell P (2000) Manual of rabbit medicine and surgery, Gloucester, British Small Animal Veterinary Association.

37. Mitruka BM and Rwansley H (1977) Clinical, biochemical and hematological references values in normal experimental animals. Masson publishing, New York, USA, 32(1): 106-112.

38. Togun VA and Oseni BSA (2005) Effect of low-level inclusion of biscuit dust in broiler finisher diet apparently healthy red sokoto goats. Proc. of the $27^{\text {th }}$ Annual Conf. of Nig. Soc. For Anim. Prod, pp. 50-53.

39. Yeong SW (1999) Efffect of dietary protein on growth performance in village chicken. Proc. National IRPA Seminar Agric Sector pp. 25192520 .

40. Abass PA, David DI, Edward A, Zira KE and Midak A (2012) Effect of age, sex and management system on some hematological parameters of intensively and semi intensively keep chicken in mubi, Adamawa state, Nig. Iranian Jou Of Applied Ani Sci 2(3): 277-282.

41. Esonu BO, Emenalom 00, Udedibie A, Berbert U, Ekpor CF. et al. (2012) Performance and chemistry of weaner pigs fed raw mucuna bean meal. Trop Anim Prod Invest 4: 49-54.

42. Afolabi K D, Akinsoyinii AO, Olajide R and Akinleye SB (2001) Haematological parameters of the local chickens fed varying dietary levels of palm kernel cake. Proc.

43. Cheeke ON and Nobert HO (2000) Serum biochemical parameters in clinically healthy dogs in Ibadan. Tropical Vert. 16: 3-4.

44. Medirabbit (2011) Complete blood count and biochemical reference values in rabbits.

45. Ozkan C, Kaya, A and Akgul Y (2012) Normal values of heamatological and serum biochemical parameters in serum and urine of New Zealand white rabbits. World Rabbit Science 20: 253-259.

46. Gwana AM., Bako MM, Bagudu BY, Sadiq, A and Abdullahi MM (2014) Determinations of phytochemicals, minerals and vitamins of different varieties of water melon seeds cultivated in Borno State, North Eastern Nigeria. International Journal of Nutrition and Food Sciences. 3(4): 238-245.

47. Doyle D William Hawson (2006) The father of Heamatology Br J Hermatology, 133(4): 375-381.

48. Duncan DB (1955) Multiple Range and Multiple F-Test Biometrics 11(1): 1-42.

49. Scott HM (1965) Measurement of Albino Acid content of fish meal protein by chick growth assay, P.Sc pp: 395-65.

50. A.O.A.C (2000). Association of Official Analytical Chemists. Official Methods of Analysis $19^{\text {th }}$ Edition Washington, D.C pp: 69-77.

51. Dacie JV and Lewis SM (1991) Practical Haematology $7^{\text {th }}$ edition ELBS with Church hill, England.

52. Roschian L, Bernat E and Grubber W (1974) Enzmtrache Bestimung des gesamcholestrins in serus l clin Chein Bioc/iem 12: 403-407.

53. Statistical Analysis Systems Institute Inc. (1997) SAS User guide statistic, version 6 edition. Gary, New York, USA.

54. Onwuka GI (2005) Food analysis and instrumentation, theory and practice. Nap. Print Lagos, Nigeria.

55. Yamaguchi M, (2006) World Vegetables: Principles, Production and Nutritive Values. AVI Publishing Co, Westport, USA.

56. Fila WA, Ifam EH, Johnson JT, Odey MO, Effiong EE, Dasofunjo K, and Ambo EE (2013) Comparative proximate compositions of watermelon Citrullus Lanatus, Squash cucurbita pepo'l and Rambutan, Nephelium Lappaceun. International Journal of Science and Technology 2(1): 8188. 
cC) This work is licensed under Creative

Commons Attribution 4.0 License

DOI: 10.19080/AAPS.2019.01.555555
Your next submission with Juniper Publishers will reach you the below assets

- Quality Editorial service

- Swift Peer Review

- Reprints availability

- E-prints Service

- Manuscript Podcast for convenient understanding

- Global attainment for your research

- Manuscript accessibility in different formats ( Pdf, E-pub, Full Text, Audio)

- Unceasing customer service

Track the below URL for one-step submission https://juniperpublishers.com/online-submission.php 